\title{
Integrated effects of herbicides and foliar fertilizer on corn inbred line
}

\author{
Milan Brankov ${ }^{1 *}$, Milena Simic ${ }^{1}$, Jelena Mesarovic ${ }^{1}$, Branka Kresovic ${ }^{1}$, and Vesna Dragicevic ${ }^{1}$ \\ 'Maize Research Institute “Zemun Polje”, Slobodana Bajica 1, 11185 Zemun Polje - Belgrade, Serbia. \\ "Corresponding author (brankovmilan@gmail.com).
}

Received: 9 August 2019; Accepted: 5 November 2019; doi:10.4067/S0718-58392020000100050

\begin{abstract}
Plant response to herbicides is one of the most essential points in corn (Zea mays L.) production, especially in inbred lines. Weed abundance is higher in corn lines comparing to hybrids. Insufficient herbicide selectivity in lines crop can be a limiting factor for their application. Weed control today is based on Integrated Weed Management (IWM) approach, i.e. to use all possible methods and measures for weed control and better crop fitness. In this research, sensitivity of one corn inbred line (selection based on previous research) was tested to two sulfonylurea herbicides in treatments with and without foliar fertilizer. Treatments included recommended and double field doses and control (no herbicide), with and without foliar fertilizer. Herbicides and foliar fertilizer were applied as a mixture. In a $3 \mathrm{yr}$ field experiment, herbicides expressed different selectivity to the tested line. The line was further tested in controlled conditions for dose-response analyses in order to determine variations in biomass and biochemical compounds levels. The double dose of foramsulfuron affected fresh matter significantly $(p<0.05)$ with $90 \%$ decrease, compared to control. An experiment in controlled conditions showed increased tolerance to herbicides in treatments with foliar fertilizer - according to higher effective doses $\left(\mathrm{ED}_{10}, \mathrm{ED}_{50}\right.$, and $\mathrm{ED}_{90}$ ) estimated, indicating higher plant tolerance to herbicides when foliar fertilizer was applied. In corn leaves the highest herbicide dose and foliar fertilizer induced slight reduction of concentrations of free thiol groups, soluble proteins and phytic $\mathrm{P}$ (to $14.1 \%, 9.3 \%$ and $9.9 \%$, respectively) and increased phenolics concentration (up to $26.7 \%$ ) compared to treatment without herbicide application. Obtained results indicate positive effects of foliar fertilizer when it is applied in mixture with herbicides, and foliar fertilizing should be considered as important strategy in obtaining higher yields.
\end{abstract}

Key words: Dose response, fertilizing, sulfonylurea, Zea mays.

\section{INTRODUCTION}

Corn (Zea mays L.) is the third highest crop in sown area in the world (FAO, 2015) with sown area of 1.2 million hectares. It is the most important arable crop in Serbia, with relatively low average grain yields of $5.1 \mathrm{t} \mathrm{ha}^{-1}$ (Statistical Office of the Republic of Serbia, 2017). Weed management is an essential measure in growing practices, especially in corn inbred lines. Soltani et al. (2016) reported an average of 50\% yield losses caused by weeds in corn crop. Weed abundance is higher in inbred lines crop comparing to hybrids. In general, until rows close weeds can significantly decrease yield in hybrid crop, while in inbred lines that period is often longer and herbicide application is highly reasonable - pre-emergence, as well as post-emergence. Corn inbred lines are homozygous, and due to inbreeding, they have lower vigour and slower growth and development. These factors can lead to increase sensitivity to various biotic and abiotic factors, including herbicides (Stefanovic et al., 2010). In general, corn lines are more sensitive to herbicides than hybrids, meaning lack of herbicide selectivity can be a limiting factor for their application. In Serbia, herbicides are registered for application in hybrids, but not particularly in inbred lines. Only with experiments in field conditions that continue minimally $2 \mathrm{yr}$, and/ or in controlled condition proper advices for producers could be given regarding herbicide application. 
Herbicides can cause visible plant damages or slow down plant development leading to decrease grain yield. In Serbia, Stefanovic et al. (2010) reported several problems with herbicide selectivity, especially in seed corn production, such as significant injuries, caused by post-emergence herbicides, mainly sulfonylureas. Brankov et al. (2015) also showed that sulfonylurea herbicides caused significant visible damages and reduced growth parameters in corn inbred lines, while triketons (bleaching herbicides, 4-hydroxyphenylpyruvate dioxygenase [HPPD] inhibitors) expressed higher selectivity. It is evident that herbicides can cause more stress in corn lines compared to hybrids. This stress can be temporary or permanent (de Carvalho et al., 2009) and is mainly based on production of free radicals, such as reactive oxygen species (ROS) - oxidative stress (Tripathy and Oelmüller, 2012). ROS could also affect photosynthetic apparatus (chlorophyll and carotenoids concentration), decreasing photosynthetic rate and efficiency and increasing lipid peroxidation (Langaro et al., 2017). The elevated ROS production can further alter concentration of biochemical compounds, such as soluble proteins and antioxidants (thiolic groups of proteins, phenolics, carotenoids, etc.) having as a consequence decrease of 2,2-diphenyl-1-picrylhydrazyl free radical (DPPH) reduction potential (García-Díaz et al., 2018), as well as arrest of biosynthetic processes (de Carvalho et al., 2009; Hassan et al., 2011).

When plants requirements are optimally satisfied with essential elements it can easier overcome stressful conditions. Optimal plant nutrition is the basis for every plant production. Plants mainly assimilate minerals through the root system and in lesser extent via leaves. Uptake through leaves is possible due to similar histology of root and leaves stems. This is important because plants are not able to absorb minerals from soil. If minerals are in insoluble forms, in deficiency, or soil characteristics deplete availability, foliar fertilizers application can be one of solution for this problem (Agegnehu et al., 2017). These chemicals may contain macro- and microelements, amino acids and growth stimulators. Foliar fertilizers have been showed to increase plant tolerance to various biotic and abiotic factors (Bulgari et al., 2014). Negative herbicide effects could be diminished by foliar fertilizer application (Brankov, 2016).

The aim of this research was to examine morpho-physiological response of corn line to herbicides, as well as potentially restorative effect of foliar fertilizer, based on activity of primary non-enzymatic antioxidants.

\section{MATERIALS AND METHODS}

\section{Experimental site}

Field studies were conducted at the experimental field of the Maize Research Institute 'Zemun Polje' in the vicinity

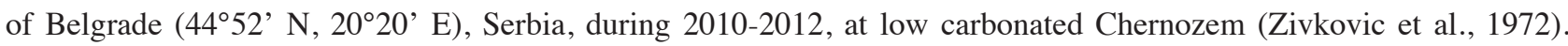
Winter wheat was previous crop. The tested inbred line was selected based on previous research (Stefanovic et al., 2010) regarding lines sensitivity to various herbicides. The line belongs to the early maturity group, with mainly pronounced susceptibility to various stressful factors. The corn inbred line was sown on 28 April in 2010 and 2011, and 3 May 2012, with $70 \mathrm{~cm}$ row spacing and $25 \mathrm{~cm}$ between plants, with elementary plot area of $16.8 \mathrm{~m}^{2}$. The four-replicate trail was set up according to the split-plot arrangement.

\section{Herbicides and foliar fertilizer application}

When corn plants developed 5-6 leaves (15-16 BBCH) herbicides and foliar fertilizer were applied as a mixture. Two sulfonylurea herbicides were applied at recommended dose (RD) for use in hybrid corn, as well as in double dose (DD): rimsulfuron (1-[4,6-dimethoxypyrimidin-2-yl]-3-[3-ethylsulfonylpyridin-2-yl]sulfonylurea, 15 and $30 \mathrm{~g}^{2}$ ai ha ${ }^{-1}$; Tarot 25-WG, Syngenta, Basel, Switzerland) and foramsulfuron (2-[\{4,6-dimethoxypyrimidin-2-ylcarbamoylsulfamoyl]-4formamido- $N, N$-dimethylbenzamide, 45 and $90 \mathrm{~g}_{\text {ai ha }}{ }^{-1}$; Equip, BASF, Ludwigshafen, Germany). Selected herbicides have excellent efficiency in grass weed control, but some problems with their selectivity were reported. Foliar fertilizer (FF) (12-4-6+0.2 MgO+ME inorganic complex foliar fertilizer with secondary and micro-elements and amino acids, $12 \%$ $\mathrm{N}, 4 \% \mathrm{P}, 6 \% \mathrm{~K}, 0.2 \% \mathrm{Mg}, 0.01 \% \mathrm{~B}, 0.01 \% \mathrm{Cu}, 0.01 \% \mathrm{Mn}, 0.005 \% \mathrm{Mo}, 0.005 \% \mathrm{Zn}$, and amino acids; Activeg, Angibaud \& Spécialités, La Rochelle, France) was applied at the same corn stage in recommended dose of $4 \mathrm{~L} \mathrm{ha}^{-1}$. Applications were made using a $\mathrm{CO}_{2}$-pressurized backpack sprayer (Bellspray Inc dba R\&D Sprayers, Opelousas, Louisiana, USA) equipped with TeeJet XR11002-SS nozzles (TeeJet Spraying Systems, Wheaton, Illinois, USA) calibrated to deliver a spray volume of $140 \mathrm{~L} \mathrm{ha}^{-1}$ of solution at $275.8 \mathrm{kPa}$. 


\section{Bioassay in controlled conditions}

This assay was conducted to test corn line sensitivity to increased doses of foramsulfuron as the less selective compared to rimsulfuron, with and without FF application. The experiment was conducted with four replicates random block system, repeated twice. This line was grown in a greenhouse for $10 \mathrm{~d}$ up to the 3-4 leaves developed (13-14 $\mathrm{BBCH})$ and then treated with rising doses of foramsulfuron, up to 6 times higher than the recommended dose. Herbicide was applied in following doses: 0, $22.5(\mathrm{H} 1), 45(\mathrm{H} 2), 67.5(\mathrm{H} 3), 90(\mathrm{H} 4), 135(\mathrm{H} 5)$, and $170(\mathrm{H} 6) \mathrm{g}$ ai ha ${ }^{-1}$ and with FF (FH1-FH6; recommended dose), using a research spray chamber (Avico Praha, Prague, Czeck Republic) calibrated to deliver 93.5 $\mathrm{L} \mathrm{ha}^{-1}$ with a XR11002-SS nozzle (TeeJet Spraying Systems) at $414 \mathrm{kPa}$. Foliar fertilizer and herbicide were applied as mixture. After spraying, plants were returned to greenhouse for $7 \mathrm{~d}$ and fresh matter (FM) and DM of aboveground material were measured. Conditions in greenhouse were as followed: $12 \mathrm{~h}$ with light and $30{ }^{\circ} \mathrm{C}$ temperature and $12 \mathrm{~h}$ without light with $20{ }^{\circ} \mathrm{C}$ temperature. Humidity was $65 \%-80 \%$ and light intensity was $44 \mathrm{~W} \mathrm{~m}^{-2}$.

\section{Data collection}

Corn line response to herbicides and foliar fertilizer was observed by measuring plant aboveground FM and DM in a period of 2-3 wk after treatments, while grain yield was measured at the end of vegetation and $14 \%$ moisture was calculated.

Under controlled conditions, at the end of experiment, FM and DM of aboveground parts were measured. After drying, leaves were milled and samples were used for determination of following biochemical parameters: content of free thiolic groups (PSH) by the method of de Kok et al. (1981), soluble proteins (SP) by method of Lowry et al (1951), soluble phenolic (Phen) by the method of Simic et al. (2004) and phytic acid, expressed as phytic $\mathrm{P}\left(\mathrm{P}_{\mathrm{phy}}\right)$. Amounts were determined accordingly to the method of Dragicevic et al. (2011). Total chlorophyll (Chlor) and total carotenoids content (Carot), as well as antioxidant activity, expressed as DPPH and $\mathrm{H}_{2} \mathrm{O}_{2}$ scavenging activities, were evaluated from fresh samples. Chlor content (chlorophyll A+B) and Carot were determined with 70\% acetone extraction by the method of Saric et al. (1990). From the same extract, DPPH scavenging activity was determined by the method suggested by Abe et al. (1998) and $\mathrm{H}_{2} \mathrm{O}_{2}$ scavenging activity by the method of Ruch et al. (1989). Meteorological data, precipitation totals and temperature were presented by decades in Table 1. Temperature was expressed as growing degree days (GDDs) (Gilmore and Rogers, 1958).

\section{Statistical analysis}

Obtained data were statistically processed by ANOVA (F test), while differences between means were tested by the least significant difference test (LSD test). Interdependence between examined parameters and applied treatments were processed by principal component analysis (PCA). Results from the field experiment were presented with standard deviation (SD). Results from the controlled conditions were presented as average \pm SD from both experimental trials. Statistical analysis was performed by SPSS 15.0 (IBM Corporation, Armonk, New York, USA) for Windows Evaluation version. Data collected in

Table 1. Air temperatures presented in growing degree days (GDDs) and precipitation totals in Zemun Polje for 20102012 growth period.

\begin{tabular}{|c|c|c|c|c|c|c|c|c|}
\hline & & Apr & May & Jun & Jul & Aug & Sep & $\Sigma$ \\
\hline \multicolumn{9}{|c|}{2010} \\
\hline \multirow[t]{3}{*}{ GDDs } & $1^{\text {st }}$ decade & 2.2 & 10.0 & 9.0 & 13.0 & 13.9 & 8.6 & \\
\hline & $2^{\text {nd }}$ decade & 3.1 & 4.9 & 15.2 & 17.1 & 16.2 & 9.1 & \\
\hline & $3^{\text {rd }}$ decade & 6.1 & 10.3 & 9.2 & 13.3 & 13.9 & 7.3 & \\
\hline \multicolumn{2}{|c|}{ Precipitation, $\mathrm{mm} \mathrm{m}^{-2}$} & 44.0 & 86.2 & 180.8 & 42 & 54 & 51.1 & 458.1 \\
\hline \multicolumn{9}{|c|}{2011} \\
\hline \multirow[t]{3}{*}{ GDDs } & $1^{\text {st }}$ decade & 4.5 & 2.9 & 13.2 & 13.5 & 13.2 & 14.6 & \\
\hline & $2^{\text {nd }}$ decade & 2.5 & 7.5 & 11.7 & 17.7 & 14.0 & 14.7 & \\
\hline & $3^{\text {rd }}$ decade & 6.7 & 10.9 & 12.1 & 11.4 & 17.0 & 10.6 & \\
\hline \multicolumn{2}{|c|}{ Precipitation, $\mathrm{mm} \mathrm{m}^{-2}$} & 11.1 & 62.6 & 40.4 & 107.4 & 8.9 & 48.5 & 278.9 \\
\hline \multicolumn{9}{|c|}{2012} \\
\hline \multirow[t]{3}{*}{ GDDs } & $1^{\text {st }}$ decade & 2.5 & 10.8 & 12.5 & 20.0 & 17.8 & 14.1 & \\
\hline & $2^{\text {nd }}$ decade & 2.6 & 4.9 & 14.7 & 16.0 & 13.7 & 10.0 & \\
\hline & $3^{\text {rd }}$ decade & 8.1 & 7.6 & 16.3 & 15.4 & 17.0 & 12.3 & \\
\hline \multicolumn{2}{|c|}{ Precipitation, $\mathrm{mm} \mathrm{m}^{-2}$} & 64.2 & 66.4 & 17.5 & 30.7 & 5.8 & 26.0 & 210.6 \\
\hline
\end{tabular}


controlled conditions were processed by R statistics with "drc" package (R Foundation for Statistical Computing, Vienna, Austria). Log-logistic nonlinear regression model with four parameters was used (Streibig, 1988):

$$
Y=C+\{D-C / 1+\operatorname{Exp}[B \log x-\log E]\}
$$

where $C$ and $D$ are lower limits, $E$ is estimated effective dose values, $B$ is curve slope. With this model, based on FM and $\mathrm{DM}$, the line response was evaluated calculating $\mathrm{ED}_{10}, \mathrm{ED}_{50}$ and $\mathrm{ED}_{90}$ values.

\section{RESULTS}

\section{Response of corn line to rimsulfuron and foramsulfuron in field conditions}

According to the obtained data, applied herbicides significantly affected corn FM (Figure 1), with intensive inhibitory effect expressed by foramsulfuron. In the first and the second yr, significant reduction $(p<0.05)$ of corn line FM was recorded in most treatments with herbicides (22\%-42\%), with severe decrease by both doses of foramsulfuron (more than $20 \%$ ). In the third yr, FM decreased down to $90 \%$ in DD foramsulfuron treatment, in comparison to control. However, foliar fertilizer induced significant $(p<0.05)$ increase in FM when applied with herbicides in the first and the third year (up to $50 \%$ and $20 \%$, respectively), while in the second year, foliar fertilizer did not cause significant plant response on observed parameters $(p>0.05)$. Similar to FM, foliar fertilizer increased corn DM in all treatments with herbicides, particularly in the first and second years. The highest values were obtained in treatments with rimsulfuron. In the third year, positive effects on DM were recorded only in treatments with rimsulfuron plus FF (Figure 2). Significant grain yield decrease ( $p<$ 0.05 ) was recorded in 2010 in DD rimsulfuron (33\%) and both doses of foramsulfuron (20\% and $47 \%$ respectively) and in 2011 in DD rimsulfuron (31\%) and both doses of foramsulfuron (Figure 3). Grain yield was significantly increased by FF application (up to 40\%), compared to treatments with herbicides only. In 2012, due to herbicides and environmental impact, the lowest values of grain yield were achieved, compared to first $2 \mathrm{yr}$. In DD foramsulfuron treatment 1 mo after herbicide application corn plants died. Also, FF did not affect grain yield, due to meteorological condition.

\section{Response of corn line in controlled conditions}

Increased doses of foramsulfuron reduced FM and DM of corn leaves, while FF when applied in mixture with herbicide, mitigated reduction of FM and DM, compared to treatments with only herbicides. In the dose-response bioassay for FM, estimated $\mathrm{ED}_{50}$ value was $36.4 \pm 1.6 \mathrm{~g}$, while in $\mathrm{FF}+$ herbicide combination it was $47.9 \pm 1.9 \mathrm{~g}$. Similar results were also achieved for DM: $\mathrm{ED}_{50}$ was $39.6 \pm 1.6 \mathrm{~g}$ for herbicide treatment, while it was $53.9 \pm 1.41 \mathrm{~g}$ for herbicide $+\mathrm{FF}$ (Figure 4).

Figure 1. Effects of applied treatments on corn fresh matter (mean + SD).

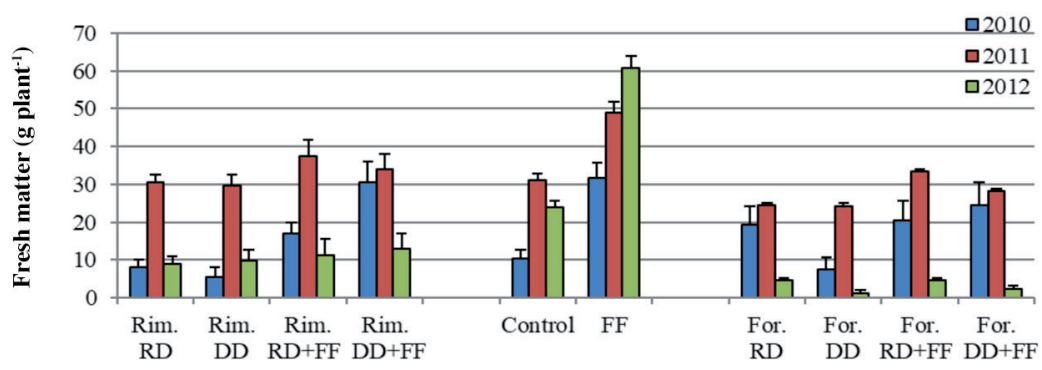

Rim.: Rimsulfuron; For.: foramsulfuron; RD: recommended dose of herbicide; DD: double dose of herbicide; FF: foliar fertilizer.

Figure 2. Effects of applied treatments on corn dry matter (mean +SD).

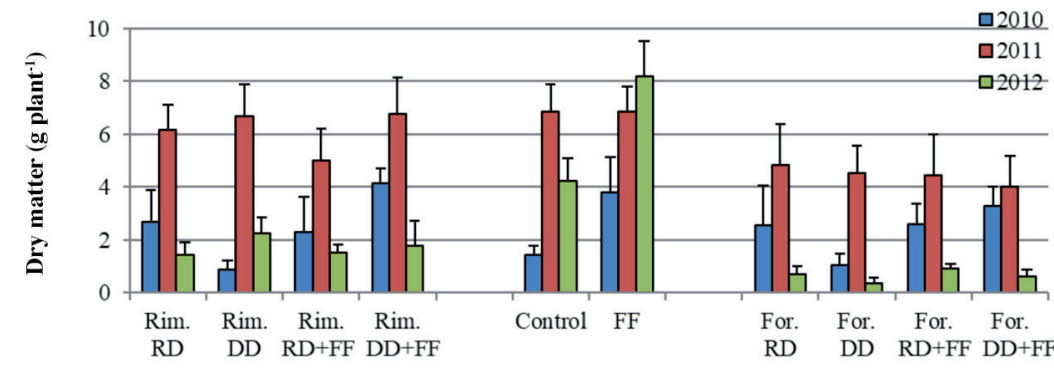

Rim.: Rimsulfuron; For.: foramsulfuron; RD: recommended dose of herbicide; DD: double dose of herbicide; FF: foliar fertilizer. 
This illustrates positive effect of applied fertilizer with herbicides. In treatment $22.5 \mathrm{~g}$ herbicide, higher FM and DM were measured in treatments containing FF for $10.5 \%-13.0 \%$ and $9.9 \%-15.0 \%$, respectively, compared to treatments without FF. Similar results were obtained in treatment $90 \mathrm{~g}$ herbicide. In treatments with herbicide + FF higher values of measured parameters were obtained $9.1 \%-12.3 \%$ and $7.8 \%-13.9 \%$, respectively, compared to no FF treatments.

Figure 3. Effects of applied treatments on corn dry matter (mean +SD).

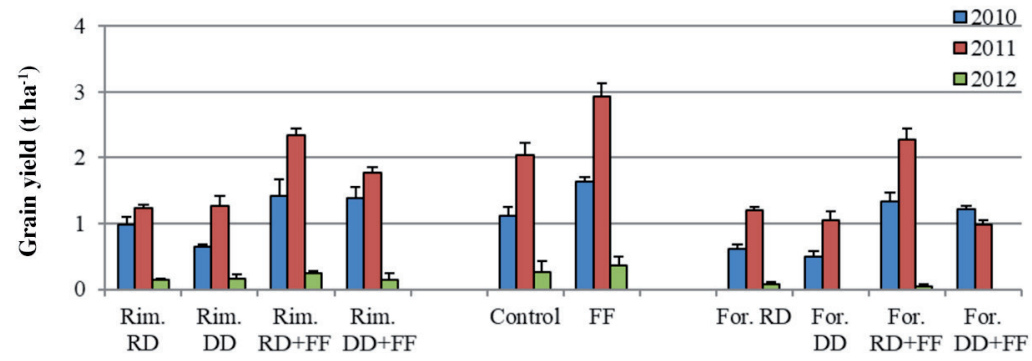

Rim.: Rimsulfuron; For.: foramsulfuron; RD: recommended dose of herbicide; DD: double dose of herbicide; FF: foliar fertilizer.

Figure 4. Influence of increased doses of foramsulfuron on fresh and dry matter content in corn line leaves.
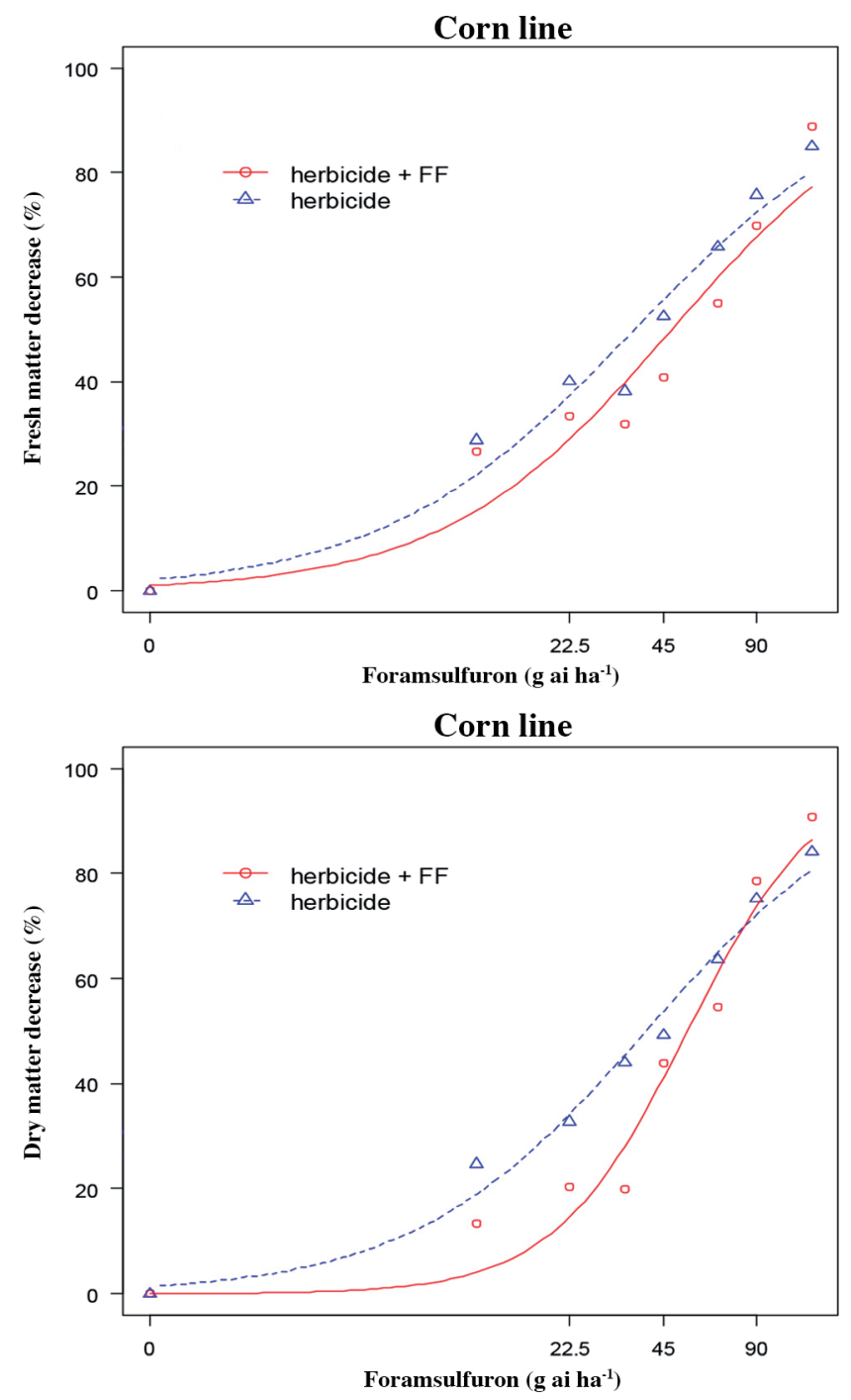


\section{Changes in biochemical compounds}

Among all tested parameters, increased doses of foramsulfuron induced mutual and significant decrease $(p<0.05)$ in concentration of SP, Phen and DPPH, while the other parameters were mainly and significantly increased (Table 2). Foliar fertilizer significantly affected the concentration of all tested parameters, applied with herbicide. When compared to control, foliar fertilizer increased significantly $(p<0.05)$ concentrations of PSH $(26.2 \%)$ and SP $(10.9 \%)$, while the concentrations of other parameters varied nonsignificantly $(p>0.05)$. With the increasing herbicide dose $+\mathrm{FF}$, concentration of $\mathrm{P}_{\text {phy }}$ and Chlor significantly decreased, with slightly higher values of $\mathrm{P}_{\text {phy }}$, in FF treatment in comparison to control. PSH, Carot and Chlor concentrations were mainly increased in all treatments with FF compared to treatments without FF $(9.1 \%-14.1 \%$; 8.0\%-68.9\% and 10.0\%-37.1\% respectively). Only $\mathrm{H}_{2} \mathrm{O}_{2}$ reduction capacity expressed fluctuations, independently on foramsulfuron dose, or combination herbicide + FF. nonsignificant variation in DPPH in all herbicide treatments were recorded, whereas FF mainly induced DPPH decrease (significantly in F and FH3 treatments, compared to control). Only in FH5 and FH6, DPPH values were increased, when compared to herbicide treatments. Results of PCA referred that PCA1 was explained by $44.66 \%$, PCA 2 by $30.21 \%$ and PCA 3 by $16.46 \%$, under the influence of different foramsulfuron doses. Phen, Carot and Chlor mainly contributed to PCA1; SP, $\mathrm{P}_{\text {phy }}$ and DPPH contributed to the second axis (PCA 2) and capacity for $\mathrm{H}_{2} \mathrm{O}_{2}$ reduction contributed to PCA 3 (Figure 5). In treatments with foramsulfuron + foliar fertilizer, PCA 1 was explained with $52.49 \%$, PCA 2 with $25.31 \%$ and PCA 3 by $15.32 \%$ in total variability. What is more, Carot and Chlor contributed positive to PCA $1, \mathrm{P}_{\text {phy }}$ and capacity for $\mathrm{H}_{2} \mathrm{O}_{2}$ reduction contributed to PCA 2, while only proteins contributed to PCA 3 (Figure 6).

\section{DISCUSSION}

Lack of herbicide selectivity in corn seed production can cause significant yield decrease. According to previous research, sulfonylurea herbicides induce specific damages on corn plants, especially in early FAO groups. However, these herbicides are efficient in controlling a majority of problematic weeds (Bozic et al., 2011). In this research, line FAO 200 maturity group responded to applied herbicides with significant injuries, especially in 2012, when meteorological conditions were unfavourable. The damages could be characterized as irreversible (de Carvalho et al., 2009) resulting in significant yield reduction and absence (foramsulfuron DD treatments in 2012). The explanation for increased sensitivity could be found in alterations of biochemical compounds, such as gradual reduction of SP, Phen and DPPH, as well as increase of PSH. This could signify the presence of oxidative stress and arrest of biosynthetic processes (Hassan et al., 2011). Results also indicated that injuries caused by high foramsulfuron doses could be

Table 2. Content of soluble phenolic (Phen), free thiolic groups (PSH), SP (soluble proteins), total carotenoids content (Carot), total chlorophyll (Chlor), phytic $\mathbf{P}\left(\mathbf{P}_{\text {phy }}\right)$, and 2,2-diphenyl-1-picrylhydrazyl free radical (DPPH) and capacity for $\mathrm{H}_{2} \mathrm{O}_{2}$ reduction in leaves of sensitive corn line (results present average $\pm \mathrm{SD}$ of two experimental trials).

\begin{tabular}{|c|c|c|c|c|c|c|c|c|}
\hline Treatments & Phen & PSH & SP & $\mathrm{P}_{\text {phy }}$ & Carot & Chlor & DPPH & $\mathrm{H}_{2} \mathrm{O}_{2}$ \\
\hline & $\mu \mathrm{g} \mathrm{g}^{-1}$ & nmol g-1 & & & $\operatorname{lg~g~}^{-1}$ & & c & \\
\hline Control & $833.46 \pm 9.44$ & $94.37 \pm 10.73$ & $145.79 \pm 3.25$ & $1.33 \pm 0.12$ & $0.034 \pm 0.0005$ & $0.162 \pm 0.001$ & $92.16 \pm 2.75$ & $44.72 \pm 0.05$ \\
\hline H1 & $850.11 \pm 5.03$ & $110.03 \pm 19.36$ & $147.88 \pm 3.41$ & $1.88 \pm 0.16$ & $0.033 \pm 0.0005$ & $0.150 \pm 0.005$ & $90.11 \pm 1.69$ & $40.96 \pm 0.94$ \\
\hline $\mathrm{H} 2$ & $870.38 \pm 4.40$ & $113.93 \pm 2.82$ & $150.72 \pm 5.52$ & $1.96 \pm 0.08$ & $0.031 \pm 0.0002$ & $0.140 \pm 0.001$ & $88.06 \pm 1.28$ & $32.53 \pm 0.02$ \\
\hline H3 & $821.00 \pm 8.87$ & $116.73 \pm 5.98$ & $173.34 \pm 3.97$ & $1.97 \pm 0.02$ & $0.029 \pm 0.0001$ & $0.125 \pm 0.000$ & $88.51 \pm 2.09$ & $44.71 \pm 0.11$ \\
\hline $\mathrm{H} 4$ & $802.76 \pm 8.81$ & $118.73 \pm 1.13$ & $164.16 \pm 4.87$ & $1.99 \pm 0.05$ & $0.047 \pm 0.0010$ & $0.185 \pm 0.007$ & $87.70 \pm 1.52$ & $27.84 \pm 0.03$ \\
\hline H5 & $770.74 \pm 8.81$ & $152.27 \pm 8.47$ & $155.55 \pm 1.46$ & $1.99 \pm 0.02$ & $0.047 \pm 0.0024$ & $0.177 \pm 0.002$ & $88.77 \pm 1.37$ & $44.73 \pm 0.04$ \\
\hline H6 & $769.85 \pm 7.95$ & $137.49 \pm 6.22$ & $162.66 \pm 1.85$ & $1.92 \pm 0.05$ & $0.063 \pm 0.0005$ & $0.175 \pm 0.003$ & $89.10 \pm 1.46$ & $44.72 \pm 0.05$ \\
\hline $\mathrm{F}$ & $705.20 \pm 5.22$ & $119.13 \pm 5.46$ & $161.67 \pm 1.56$ & $1.40 \pm 0.12$ & $0.020 \pm 0.0004$ & $0.045 \pm 0.005$ & $74.68 \pm 1.35$ & $15.05 \pm 0.03$ \\
\hline FH1 & $750.63 \pm 6.92$ & $120.11 \pm 5.65$ & $163.67 \pm 4.87$ & $1.90 \pm 0.02$ & $0.035 \pm 0.0004$ & $0.050 \pm 0.001$ & $90.13 \pm 4.57$ & $37.99 \pm 0.83$ \\
\hline $\mathrm{FH} 2$ & $793.42 \pm 13.97$ & $112.34 \pm 5.65$ & $166.11 \pm 3.25$ & $1.88 \pm 0.22$ & $0.037 \pm 0.0001$ & $0.089 \pm 0.001$ & $88.08 \pm 2.06$ & $41.85 \pm 0.45$ \\
\hline FH3 & $746.72 \pm 18.94$ & $129.51 \pm 13.72$ & $168.06 \pm 3.90$ & $1.72 \pm 0.02$ & $0.049 \pm 0.0014$ & $0.162 \pm 0.006$ & $81.36 \pm 4.84$ & $14.50 \pm 0.41$ \\
\hline FH4 & $725.36 \pm 16.36$ & $134.70 \pm 13.55$ & $170.35 \pm 3.25$ & $1.72 \pm 0.01$ & $0.035 \pm 0.0005$ & $0.130 \pm 0.020$ & $87.60 \pm 2.84$ & $25.42 \pm 0.11$ \\
\hline FH5 & $854.36 \pm 3.77$ & $145.88 \pm 4.52$ & $147.63 \pm 3.25$ & $1.73 \pm 0.03$ & $0.048 \pm 0.0004$ & $0.138 \pm 0.008$ & $98.86 \pm 4.91$ & $20.02 \pm 0.13$ \\
\hline FH6 & $885.50 \pm 5.78$ & $130.71 \pm 4.78$ & $164.84 \pm 4.29$ & $1.75 \pm 0.05$ & $0.046 \pm 0.0004$ & $0.163 \pm 0.006$ & $92.66 \pm 2.56$ & $29.82 \pm 0.28$ \\
\hline LSD 0.05 & 22.68 & 14.70 & 2.50 & 0.11 & 0.001 & 0.018 & 5.05 & 8.20 \\
\hline
\end{tabular}

Treatments: Herbicide doses: 0, 22.5 (H1), 45 (H2), 67.5 (H3), 90 (H4), 135 (H5), and 170 (H6) g ai ha ${ }^{-1}$ and with foliar fertilizer (F) (FH1-FH6; at recommended dose). 
partially tied to oxidative stress, but not $\mathrm{H}_{2} \mathrm{O}_{2}$ overproduction. This is reflected through $\mathrm{H}_{2} \mathrm{O}_{2}$ fluctuations and slight DPPH decrease, indicating complex role of $\mathrm{H}_{2} \mathrm{O}_{2}$ in plant metabolism (Gill and Tuteja, 2010). High herbicide doses did not affect photosynthetic apparatus (Chlor and Carot), which is the opposite of Langaro et al. (2017), who obtained research with oxadiazon, pendimethalin and oxyfluorfen on rice.

Figure 5. Principal Component Analysis for soluble phenolic (Phen), free thiolic groups (PSH), soluble proteins (SP), total carotenoids content (Carot), total chlorophyll (Chlor), phytic $\mathbf{P}\left(\mathbf{P}_{\text {phy }}\right), \mathrm{H}_{2} \mathrm{O}_{2}$ content and 2,2-diphenyl-1-picrylhydrazyl free radical (DPPH) in maize leaves, influenced by different foramsulfuron doses.
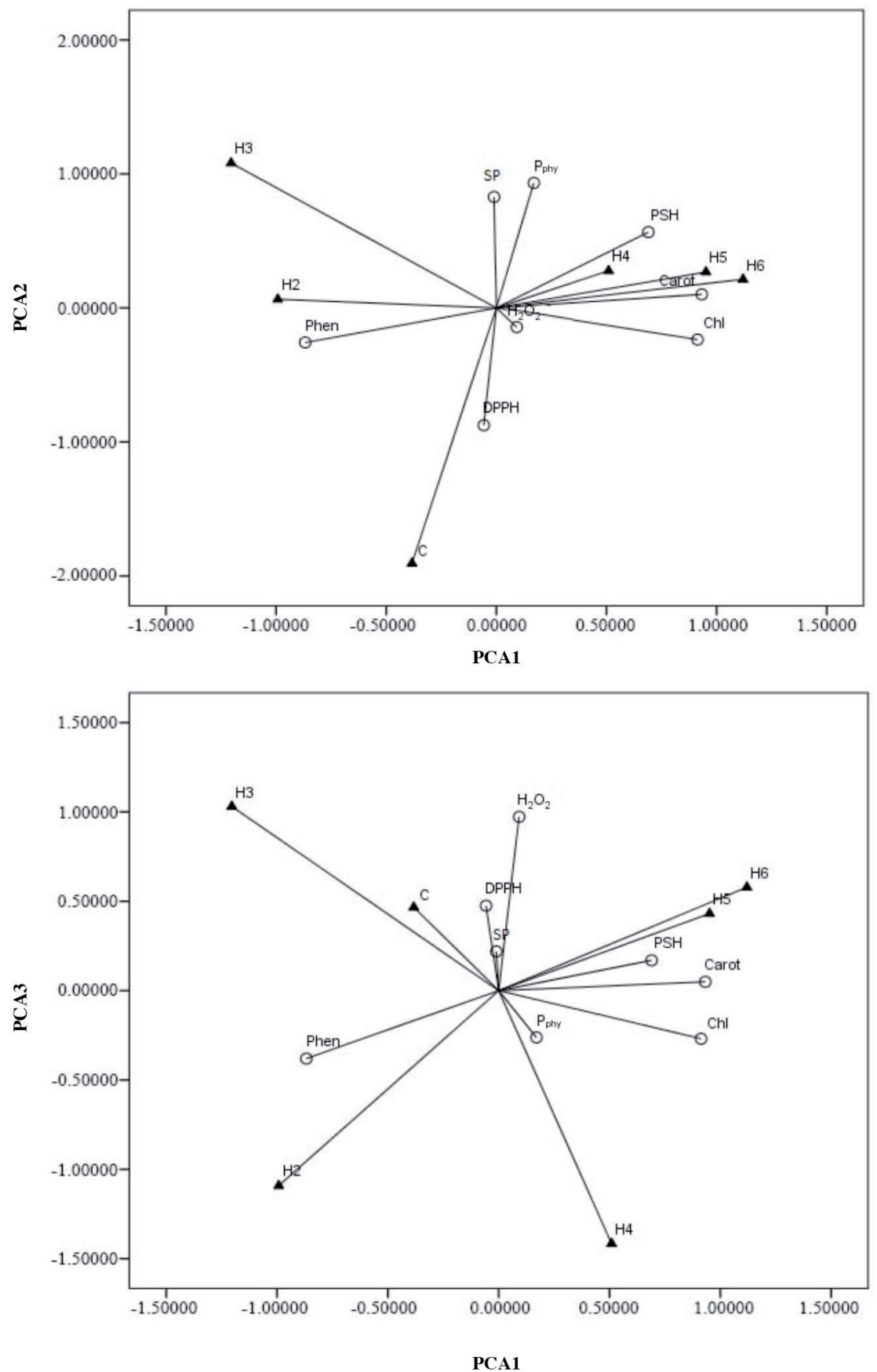

H1-H6: Herbicide doses: 0 (C), 22.5 (H1), 45 (H2), 67.5 (H3), 90 (H4), 135 (H5), and 170 (H6) g ai ha ${ }^{-1}$. 
Figure 6. Principal Component Analysis for soluble phenolic (Phen), free thiolic groups (PSH), soluble proteins (SP), total carotenoids content (Carot), total chlorophyll (Chlor), phytic $\mathrm{P}\left(\mathrm{P}_{\mathrm{phy}}\right), \mathrm{H}_{2} \mathrm{O}_{2}$, and 2,2-diphenyl-1-picrylhydrazyl free radical (DPPH) content in maize leaves, influenced by different doses of foramsulfuron $+\mathrm{FF}$.
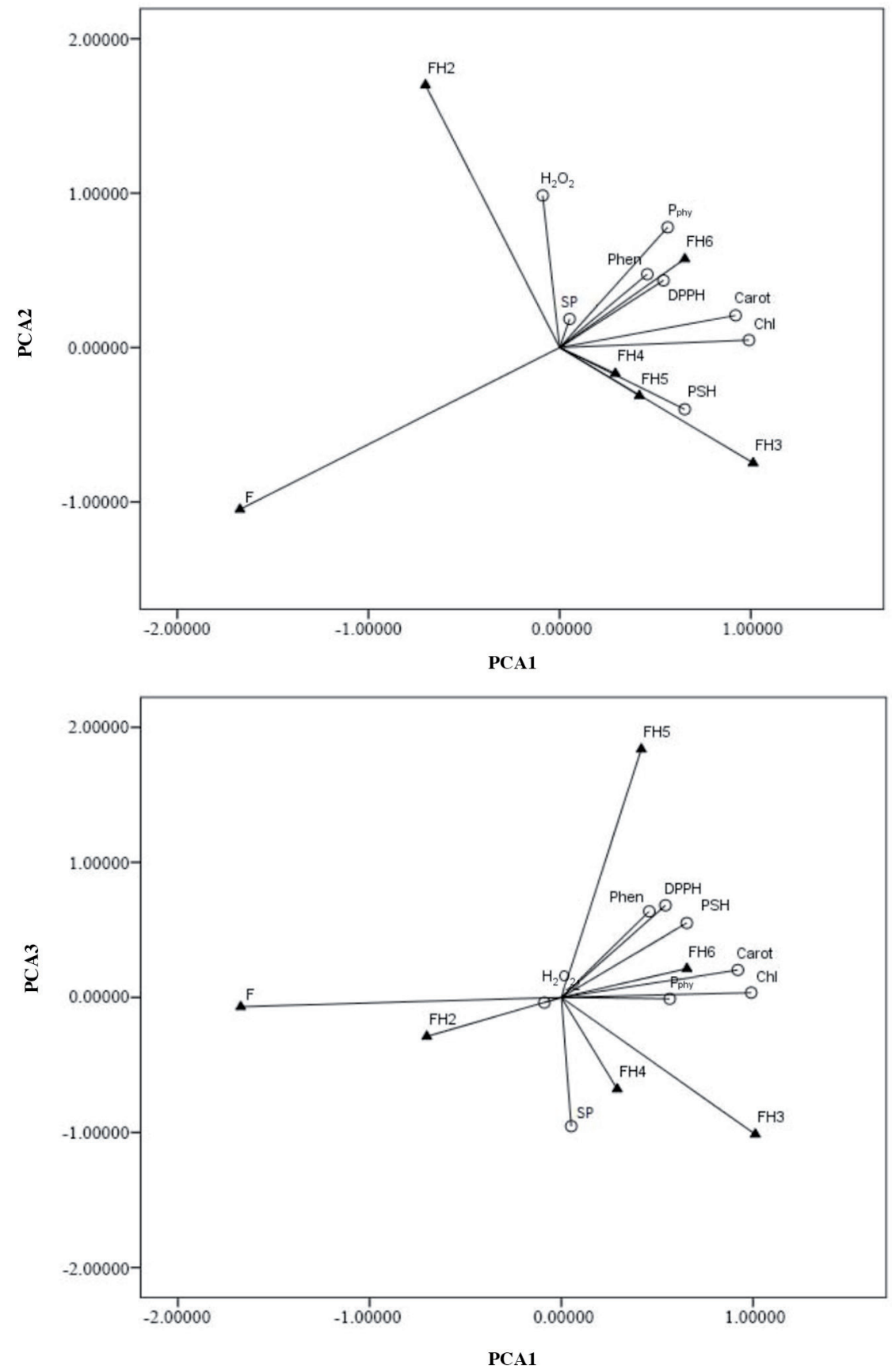

FH1-FH6: Foliar fertilizer (F) with herbicide (H; g ai ha'-1): FH1 (22.5), FH2 (45), FH3 (67.5), FH4 (90), FH5 (135), and FH6 (170).

Applied foliar fertilizer was advantageous when applied with herbicides, compared to treatments without fertilizer. IWM considers the use of all available methods and measures for weed control, giving advantages to crop against the weeds (Owen et al., 2014; Lamichhane et al., 2017). Accordingly, foliar fertilization can be considered as a part of IWM, providing better crop fitness and eliminating negative environmental factors, as well as sensitivity to herbicides (Powles and $\mathrm{Yu}, 2010)$. Foliar fertilizer containing amino acids and other nutrients enables their rapid entry and engaging in 
metabolism, providing faster regeneration of corn plants from herbicide stress (Brankov et al., 2017). This could increase their competitive potential in regard to weeds (Tagour and Mosaad, 2017). Treatments with FF had 24\%-27\% higher $\mathrm{ED}_{50}$ values in treatments with FF, compared to treatments with no FF, for FM and DM (from experiment in controlled condition). This effect could be closely linked to $\mathrm{N}$ metabolism, due to its importance in the constitution of compounds such as enzymes, nucleic acids, proteins, and chlorophyll, etc. Most of these compounds are intrinsic for growth and reproductive processes (White et al., 2014). It is also important to underline that FF in combination with foramsulfuron contributed to diminishing oxidative stress and improving biosynthesis of physiologically active compounds, such as SP, PSH, and Carot to some extent (Dragicevic et al., 2017). Increased antioxidant response is also reflected in higher concentration of Phen and increased values of DPPH reduction capacity, mainly in FH5 and FH6 treatments. An increased antioxidant system activity influenced by herbicides is reported by Liu et al. (2014). Irrespective to the tendency of an increase in Chlor concentration in treatments with foramsulfuron + FF with increased herbicide doses, generally Chlor level was lower in foramsulfuron treatments, indicating that $\mathrm{N}$ fertilization could interfere with expression of herbicide activity (Sonderskov et al., 2012).

According to PCA in treatments with increasing foramsulfuron doses, $\mathrm{SP}$ and $\mathrm{P}_{\mathrm{phy}}$ plays an important role in free radical scavenging (DPPH), while $\mathrm{H}_{2} \mathrm{O}_{2}$ scavenging capacity depends on other factors. Phen and Carot are important for chlorophyll protection. Lower foramsulfuron doses (H2) induced higher variability in Phen concentration, while higher doses, such as H5 and H6 mainly influenced variations in PSH, Carot and to some extent Chlor concentration, indicating the importance of non-enzymatic antioxidants in herbicide detoxification (Brankov et al., 2017; Dragicevic et al., 2017). However, application of foliar fertilizer shifted protective mechanisms in the way that $\mathrm{P}_{\text {phy }}$ is important for $\mathrm{H}_{2} \mathrm{O}_{2}$ scavenging potential, while Carot is still the main protective factor for chlorophyll preservation. When foliar fertilizer is applied alone or with low doses of foramsulfuron, it causes variability in $\mathrm{H}_{2} \mathrm{O}_{2}$ scavenging capacity, while in combination with higher foramsulfuron doses, DPPH, Phen and PSH concentrations were varied.

\section{CONCLUSIONS}

In this research, negative effects of foramsulfuron on the examined corn line were confirmed. Besides the reduction of FM, DM and grain yield, it was confirmed that this herbicide promoted oxidative stress. Foliar fertilizer significantly affected all observed parameters, expressing some restorative potential, such as antioxidants concentration. According to obtained results, foliar fertilizer application together with herbicides gives higher possibilities for safer herbicide application in corn seed production. Also, foliar fertilizing should be considered as a part of integrated weed management system.

\section{ACKNOWLEDGEMENTS}

This research was supported by Ministry of Education, Science and Technological Development of the Republic of Serbia (Grant Nr TR 31037). Authors are thankful to Kasey Schroeder, North Platte, Nebraska, USA, for help and suggestion in language editing.

\section{REFERENCES}

Abe, N., Murata, T., and Hirota A. 1998. Novel DPPH radical scavengers, bisorbicillinol and demethyltrichodimerol, from a fungus. Bioscience, Biotechnology and Biochemistry 62:661-666. https://doi.org/10.1271/bbb.62.661.

Agegnehu, G., Srivastava, A.K., and Bird, I.M. 2017. The role of biochar and biochar-compost in improving soil quality and yield performance: A review. Applied Soil Ecology 119:156-170. https://doi.org/10.1016/j.apsoil.2017.06.008.

Bozic, D., Saric, M., Elezovic, I., and Vrbnicanin, S. 2011. Reaction of Xanthium strumarium L. and Helianthus annuus L. on nicosulfuron. Acta biologica Iugoslavica - Series G: Acta Herbologica 20(1):15-24.

Brankov, M. 2016. Effects of herbicides and foliar fertilizer on maize inbred lines. PhD Thesis. 130 p. University of Belgrade, Faculty of Agriculture, Phytomedicine Department, Belgrade, Serbia. https://fedorabg.bg.ac.rs/fedora/get/o:14316/ bdef:Content/get.

Brankov, M., Dragicevic, V., Simic, M., Filipovic, M., Kresovic, M., and Mandic, V. 2017. Diminishing herbicide stress in maize inbred lines by application of foliar fertilizer. Journal of Environmental Protection and Ecology 18(4):1440-1449. http://www.jepe-journal.info/journal-content/vol-18-no4. 
Brankov, M., Simic, M., Dragicevic, V., Vrbnicanin, S., and Spasojevic, I. 2015. Genotype dependent tolerance to herbicides of maize (Zea mays L.) inbred lines. Genetika 47(1):97-106. doi:10.2298/GENSR1501097B.

Bulgari, R., Cocetta, G., Trivellini, A., Virnieri, P., and Ferrante, A. 2014. Biostimulants and crop responses. Biological Agriculture and Horticulture 31(1):1-17. https://doi.org/10.1080/01448765.2014.964649.

de Carvalho, J.P., Nicolai, M., Ferreira, R., Figueira, A.V., and Christoffoleti, P.C. 2009. Herbicide selectivity by differential metabolism: Considerations for reducing crop damages. Science Agriculture (Piracicaba, Braz.) 66(1):136142. http://dx.doi.org/10.1590/S0103-90162009000100020.

de Kok, L.J., de Kan, P.J.L., Tanczos, G., and Kupier, J.C. 1981. Sulphate induced accumulation of glutathione and frosttolerance of spinach leaf tissue. Physiologia Plantarum 53:435-438. https://doi.org/10.1111/j.1399-3054.1981 .tb02727.

Dragicevic, V., Simic, M., Jovanovic-Radovanov, K., Brankov, M., and Srdic J. 2017. Reaction of susceptible maize inbred lines to herbicides. Genetika 49(3):765-774. https://doi.org/10.2298/GENSR1703765D.

Dragicevic, V., Sredojevic, S., Peric, V., Nisavic, A., and Srebric, M. 2011. Validation study of a rapid colorimetric method for the determination of phytic acid and inorganic phosphorus from seeds. Acta Periodica Technologica 42:11-21. doi:10.2298/APT1142011D.

FAO. 2015. Statistical pocketbook. p. 26-30. Food and Agriculture Organization (FAO), Rome, Italy. Available at http://www.fao.org/3/a-i4691e.pdf (accessed October 2019).

García-Díaz, Y.D., Aquino-Bolaños, N.E., Chávez-Servia, L.J., Vera-Guzmán, M.A., and Carrillo-Rodríguez, C.J. 2018. Bioactive compounds and antioxidant activity in the common bean are influenced by cropping season and genotype. Chilean Journal of Agricultural Research 78(2):255-265. http://dx.doi.org/10.4067/S0718-58392018000200255.

Gill, S.S., and Tuteja, N. 2010. Reactive oxygen species and antioxidant machinery in abiotic stress tolerance in crop plants. Plant Physiology and Biochemistry 48(12):909-930. https://doi.org/10.1016/j.plaphy.2010.08.016.

Gilmore, E.C., and Rogers, R.S. 1958. Heat units of measuring maturity in corn. Agronomy Journal 50:611-615. http://dx.doi.org/10.2134/agronj1958.00021962005000100014x.

Hassan, M.N., El-Sayed, K.A.A., Ebeid, T.H., and Nemat Alla, M.M. 2011. Molecular aspects in evolution of sunflower tolerance to drought by boron and calcium foliar sprays. Acta Physiologiae Plantarum 33(2):593-600. http://doi.org/10.1007/s11738-010-0585-8.

Lamichhane, J.R, Devos, Y., Beckie, H.J., Owen, M.D.K., Tillie, P., and Messéan, A. 2017. Integrated weed management systems with herbicide-tolerant crops in the European Union: lessons learnt from home and abroad. Critical Reviews in Biotechnology 37:459-475. https://doi.org/10.1080/07388551.2016.1180588.

Langaro, A.C., Agostinetto, D., Ruchel Queli, G., Rodrigues, J., and Perboni, L.T. 2017. Oxidative stress caused by the use of preemergent herbicides in rice crops. Revista Ciência Agronômica 48(2):358-364. https://dx.doi.org/10.5935/1806-6690.20170041.

Liu, X., Qi, C., Wang, Z., Li, Y., Wang, Q., Guo, M., et al. 2014. Effects of picloram herbicide on the physiological response of Eupatorium adenophorum Spreng. Chilean Journal of Agricultural Research 74(4):439-444. http://dx.doi.org/10.4067/S0718-58392014000400010.

Lowry, O.H., Rosenbrough, N.J., Farr, A.L., and Randal, R.J. 1951. Protein measurement with folin-phenol reagent. Journal of Biological Chemistry 193:265-275. http://www.jbc.org/content/193/1/265.long.

Owen, M.D.K., Beckie, J.H., Leeson, Y.J., Norsworthy, K.J., and Steckel, E.L. 2014. Integrated pest management and weed management in the United States and Canada. Pest Management Science 71(3):357-376. https://doi.org/10.1002/ps.3928.

Powles, B.S., and Yu, Q. 2010. Evolution in action: Plant resistant to herbicides. Annual Review of Plant Biology 61:317-347. https://doi.org/10.1146/annurev-arplant-042809-112119.

Ruch, R.J., Cheng, S.J., and Klaunig, J.E. 1989. Prevention of cytotoxicity and inhibition of intercellular communication by antioxidant catechins isolated from Chinese green tea. Carcinogenesis 10:1003-1008. https://doi.org/10.1093/carcin/10.6.1003.

Saric, M.R., Kastori, R.R., Petrovic, M., Stankovic, Z., Krstic, B.D., et al. 1990. Practicum for Plant Physiology. Scientific Book, Belgrade,Serbia (In Serbian).

Simic, A., Sredojevic, S., Todorovic, M., Dukanovic, L., and Radenovic, C. 2004. Studies on the relationship between content of total phenolics in exudates and germination ability of maize seed during accelerated aging. Seed Science and Technology 32:213-218. http://dx.doi.org/10.15258/sst.2004.32.1.22.

Soltani, N., Dille, J., Burke, I., Everman, W., Van Gessel, M., Davis, V., et al. 2016. Potential corn yield losses from weeds in North America. Weed Technology 30(4):979-984. doi:10.1614/WT-D-16-00046.1.

Sonderskov, M., Swanton, C.J., and Kudsk, P. 2012. Influence of nitrogen rate on the efficacy of herbicides with different modes of action. Weed Research 52:169-177. https://doi.org/10.1111/j.1365-3180.2012.00906.x.

Statistical Office of the Republic of Serbia. 2017. Statistical yearbook of the Republic of Serbia. http://pod2.stat.gov.rs/ ObjavljenePublikacije/G2017/pdf/G20172022.pdf (accessed October 2019).

Stefanovic, L., Simic, M., and Dragicevic, V. 2010. Studies on maize inbred lines susceptibility to herbicides. Genetika 42(1):155-168. doi:10.2298/GENSR1001155S. 
Streibig, J.C. 1988. Herbicide bioassays. Weed Research 28:479-484. https://doi.org/10.1111/j.1365-3180.1988.tb00831.x.

Tagour, R.M.H., and Mosaad, I.S.M. 2017. Effects of foliar enrichment and herbicides on maize and associated weeds irrigated with drainage water. Annals of Agricultural Sciences 62(2):183-192. https://doi.org/10.1016/j.aoas.2017.11.004.

Tripathy, C.B., and Oelmüller, R. 2012. Reactive oxygen species generation and signaling in plants. Plant signalling and behaviour 7(12):1621-1633. https://doi:10.4161/psb.22455.

White, J.W., George, S.T., Hammond, P.J., and James, K.E. 2014. Improving crop mineral nutrition. Plant and Soil 384(1-2):1-5. http://www.mdpi.com/journal/agriculture/specialissues/plantnutrientsdynamics.

Zivkovic, B., Nejgebauer, V., Tanasijevic, Dj., Miljkovic, N., Stojkovic, L., and Drezgic, P. 1972. Soils of Vojvodina. Institute for Agricultural Research, Novi Sad, Serbia (In Serbian). 